\section{My Heroes}

Garbor B. Levy

An impractical introvert in an ivory tower is the popular image of a scientist - anything but heroic. Yet science has many heroes. I ran into some while searching for the identities of the scientists who originated the Bouguer-Lambert-Beer Law. There is nothing overtly heroic about August Beer, except the heroic dimensions of his mother's maiden name: Maria Anna Antoinette Walburga Franciska Josefine Dupont. He was simply a successful high school science teacher turned professor. Lambert's career, however, has some heroic aspects. Born in Mulhouse as a son of a tailor a century before Beer, he could not get even a high school education. Largely self-taught, he broke through the national and social barriers of his day and ended up in Berlin as a respected scientist and a member of the Prussian Royal Academy. The documented genuine hero of this triumvirate is, however, Pierre Bouguer, mathematician and professor at Le Havre. He was one of the leaders of the heroic expedition of 1735 to Ecuador, initiated by the French Academy of Sciences.

This undertaking was truly heroic. It took some eight years to complete. Besides traversing the Atlantic under sail, traveling thousands of miles on horseback and by mule, and climbing the Andes in freezing temperatures in oxygen-poor air largely by foot, it required leadership in these dangers, which also included political turmoil and murders. Some may call this heroic scientific expedition quixotic, because the purpose was basically foolish. It was prompted by the mistaken idea of Dominique Cassini that our earth is a prolate spheroid (egg-shaped) rather than an oblate flattened spheroid as proposed by Newton, which was generally accepted by then. But the Cassinis were a powerful clan of astronomers who exerted a reactionary force through generations in French astronomy. The first Cassini moved to France in 1669 to the court of Louis XIV. He refused to accept the centuries-old heliocentric view of Copernicus. His son finally accepted it but did not embrace Kepler's work on planetary motions. Then the grandson supported the egg-shaped earth view. Because he was so influential, the Academy decided to mount the monstrous expedition to the equator in South America, to prove or disprove this theory. It was particularly foolish because they also sent an expedition to the Arctic circle, which would have sufficed. This destination was not easy either, to be sure. Those scientists had to spend a winter at extremely cold temperatures well below $100^{\circ}$ on the scale of Celsius, who took part in the expedition. (The temperature scale we call Celsius is actually due to Christine or to Linné, who reversed the scale of Celsius, which had boiling water at zero and the freezing point at $100^{\circ}$.) They proved that the earth is a flattened sphere, as proposed by Newton. Unnecessary as the perilous South American expedition may have been, it does not diminish the heroism of Bouguer.

France furnished other heroes of science. Lavoisier is one of my heroes, even though he was beheaded, not so much for initiating quantitative chemistry as for being part of the establishment. Nevertheless, the intellectual majesty of his Traité élementaire de Chimie is

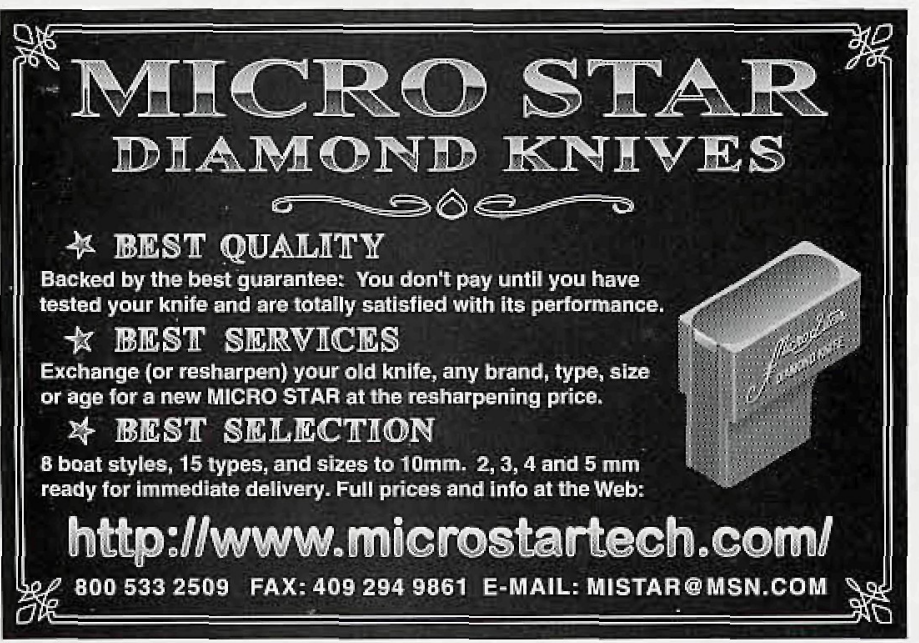

overwhelming. Also remarkable is that many pictures show him with his wife working alongside him. It is not known whether she only recorded data and acted as his translator or whether she had any substantive scientific input. But women were excluded from science in those days, and it took genuine heroism for a woman to succeed. A prime example is Sophie Germain, a gifted mathematician. She was prevented from attending the École Polytechnique and wisely submitted her first papers to Lagrange and Gauss under the name of $\mathrm{M}$. Leblanc. Only after they started corresponding as equals did she disclose her real name and sex. Even a half-century later, Sonya Kovalevsky, who moved from Russia to Berlin to study mathematics, had to take private lessons, because women were excluded from public lectures. Eventually, in 1884 she was appointed professor of mathematics in Stockholm. Marie Curie, eventually the holder of two Nobel Prizes, was initially viewed with the suspicion that she was only her husband's assistant. To this day, women have a tough time because the scientific establishment is extensively misogynous. In his A World Without Women (Alfred A. Knopf, New York: 1992), David Noble traces the root of this to the celibate, monastic male clergy of the Latin Middle Ages when "the glorification of God was the ultimate goal of scientific study." This may be only part of the reason, because the exclusion of women from accepted "male" pursuits is widespread in most cultures, far beyond Western Europe of the Middle Ages. Be that as it may, to this very day, women who want to do creative work in science face obstacles because of the frequent overt, and very pervasive covert, resistance. Rosalind Franklin of King's College of London University is often cited in this connection. While she may not have had the overall vision of a Watson, Crick, or Pauling, her unique X-ray studies of DNA fibers were crucial in the discovery of the double-helical structure. She felt that her boss, Maurice Wilkins, viewed her as a laboratory assistant rather than an independent researcher, as Watson put it in his biographical Double Helix (Atheneüm, New York, 1968): "Rosy had to go or be put in her place." Crick was more generous and acknowledged her contribution, but while he, Watson, and Wilkins shared the Nobel Prize in 1962, Franklin got little credit, but of course by that time her life had been cut short. Later, Watson wrote that he came to appreciate "her personal honesty and generosity, realizing years too late the struggles that an intelligent woman faces to be accepted by the scientific world which often regards women as mere diversions from serious thinking." This is what I have tried to express here. Women in science work against great odds, and collectively, I hold them to be heroic.

Fame is ephemeral, of course. It was only by accident that great innovators such as Mendel (genetics) or Tswett (chromatography) were rediscovered. Nor is this limited to science. Even Johann Sebastian Bach in his lifetime was little known outside his own circles and was forgotten until Mendelssohn discovered his music half a century later. Munkácsy was one of the most prominent painters at the turn of the century in Europe, and in 1940 one of his great canvases of the aging Milton was still prominently displayed in the New York Public Library. Today, you would be hard-pressed to find anybody in New York who knows of Munkácsy. Similarly, we may know the names of a few generals, but who knows the names of the genuine war heroines decorated with the Congressional Medal of Honor?

If you think of it, the spectacular French expedition to the equator contributed little to science as compared to the quiet labors of brother Johann Gregor Mendel in his monastery with his pea plants. The edifice of science is built of small bricks laid down by individual and collective effort. There are many men and women who work in virtual anonymity who do great works, even though the rewards in money and honor are meager. It is innate curiosity that motivates science, and the excitement of finding new truths is almost like magic. This is why so many pursue careers in science and technology, not merely to make a living, but for the pleasure and excitement of their work. these unknown and uncounted are my ultimate heroes.

\footnotetext{
This article is one of a series of Dr. Gabor B. Levy's essays on science and society containing thought-providing editorials previously published in International Scientific Communications journals. The book expresses the author's point of view on such subjects as Our Saciety, Our Economy, Ethics, Lawyers and the Law, Health and Medicine, Statistics, Science, Pseudoscience, Metrology, and New Directions. Size $81 / 2{ }^{\prime \prime} \times 5 \frac{1}{2}$. Price only $\$ 10.99$ plus $\$ 3.50$ for shipping and handling. Order now by check or money order, as supplies are limited. International Scientific Communications, Inc, 30 Controls Drive, Shelton, CT 06484
} 
$\checkmark$ American Type Culture Collection (ATCC) Workshops:

March 10/11 '97: Anaerobic Bacteriology

April 14/18 97: Recombinant DNA: Techniues and Applications

April 21/24 97: Polymerase Chain Reaction (PCR) Applications/Cycle

DNA Sequencing

June 4/6 '97: In Vitro Toxicology

July 7/10 97: Theory and Techniques for Extremophile Research

Nov 4/7 '97: Microbial DNA Fingerprinting

Nov 10/14 '97: Advanced Recombinant DNA: Techniques and Applica tions

Nov 17/20 '97: Polymerase Chain Reaction (PGR) Applications/Cycle

DNA Sequencing

Sept 8/10 97: Cell Culture and Hybridomas: Quality Control and Cryopreservation

Techniques

Sept 15/16 '97: The 15th Annual ATCC Biotech Patent Forum

Sept 17/19 '97: Cytogenetic and Fluorescence In Situ Hybridization

Sept 23/26' '97: Fermentation Microbiology

Oct 6/9 97: Hybridoma Technology and Monoclonal Antibody Product Develop-

ment

Oct 15/17' '97: Microscopy/Photomicrography

Oct 15/17 97: Diagnostic Virology

Oct 22/24 97: Downstream Processing. Recovery and Purification of Proteins

Oct 27/30 97: Freezing and freeze-Drying of Microorganisms

INFORMATION: (800)359-7370, Local: (301)231-5566, Fax. (301)816-4364

$\checkmark$ Jan. 23 - May 8' 97 : Scanning Electron Microscopy Spring 1997 Course (Nassau Community College) Garden City (Long Island), NY. Stephen J. Beck: (516)572-7829

$\checkmark$ February 3/7 '97: 4th Biennial Symposium on SEM Inaging and Analysis: Applications and Techniques. Melbourne, Australia http://www.minerals.csiro.au/microscopy/amas/amas.htm

$\checkmark$ February 8/14 '97: Photonics West '97. (SPIE). San Jose, CA. Marilyn Gorsuch: (360)676-3290, Fax: (360)647-1445.

$\checkmark$ February 24/28 '97: OIM Academy: OIM User Workshop. (TSL). Klaus Behnert: (801)344-8990, Fax: (801)344-8997/

$\checkmark$ March 14/16 97: Applied Optical Microscopy for Chemists (Microscopy Marketing Education). Atlanta, GA. Barbara Foster: (800)227-5558 or (202)872-4508.

$\checkmark$ March 16/21 '97: PITTCON '97 - Atlanta, GA. (412)825-3220, Fax: (412)825-3224.

$\checkmark$ March 31 - April 4 '97: Workshop on Specimen Preparation for TEM of Materials - IV. (MRS Spring Meeting). San Francisco, CA. Scott Walck: (513)255-5791, Fax: (513)255-9019.

$\checkmark$ March 31 - April 4 '97: Materials Reliability in Microelectronics VII. (MRS Spring Meeting). San Francisco, CA. Robert Keller, (303)4977651, Fax: (303)497-5030.

$\checkmark$ April 4/6 '97: 16th Southern Biomedical Engineering Conference. (Mississippi State Univ. \& Univ. of Mississippi Medical Ctr.) Biloxi, MS. Dr. Joel D. Bumgardner: (601)325-3282, Fax: (601)325-3853.

$\checkmark$ April 19/22 97: SCANNING '97 (FAMS, Inc.) Monterey, CA. Mary K. Sullivan, (201)818-1010, Fax: (201)818-0086

$\checkmark$ April 27 - May 1'97: 19th International Conference on Cement Microscopy. Cincinnati, $\mathrm{OH}$. Louis Jany: (610)261-4429, Fax: (610)261-4430.

$\checkmark$ May 8/16 '97: Analytical \& Quantitative Microscopy (Marine Biological Lab) Woods Hole, MA. Carol Hamel: (508)289-7401.

$\checkmark$ May 10/15 '97: 30th Anniversary Scanning Microscopy and Cells and Materials 1997 Meeting. (Scanning Microscopy International). Chicago, IL. (847)524-6677. Fax: (847)985-6698. $\checkmark$ May 15/17 \& May 19/21 '97: Quantitative Image Analysis Short Course. (N.C. State Univ.) Raleigh, NC. (919)515-2261.

$\checkmark$ May 19/23 \& 26/30 '97: PASEM 97 Practical Aspects of Scanning Electron Microscopy (SEM Short Course - Univ. of Maryland). College Park, MD. Tim Maugel: (301)405-6898, Fax: (301)314-9358.

$\checkmark$ May 20/27 '97: Microinjection Techniques in Cell Biology (Marine Biological Lab) Woods Hole, MA. Carol Hamel: (508)289-7401.

$\checkmark$ May 30-June 2 '97: Korea International Scientific Instruments Exhibition '97 Seoul, Korea. Tel: 82-2-551-1112, Fax: 82-2-551-1311

$\checkmark$ June 4/7 97: 24th Annual Meeting of the Microscopical Society of Canada. Edmonton. Ray Egerton: (403)492-5095, Fax: (403)4920714.

LEHIGH UNIVERSITY MICROSCOPY COURSES:

$\checkmark$ June $9 / 13$ '97: SEM and X-ray Microanalysis

$\checkmark$ June 16/19 '98:

Advanced Scanning Electron Microscopy with Digital Image Pro cessing

Quantitative X-ray Microanalysis of Bulk Specimens \& Particles June 17/20:97: Atomic Force Microscopy \& other Scanned Probe Microscopies. 4244

Bethelem, PA. David B. Williams, (610)758-5133, Fax: (610)758-

$\checkmark$ June 4/7 97: 24th Annual Meeting of the Microscopical Society of Canada. Edmonton, Canada. Ray Egerton: (403)492-5095, Fax: (403)492-0714.

$\checkmark$ June 9/14 97: ACHEM 97 - International Meeting on Chemical Engineering, Environmental Protection and Biotechnology. Frankfurt am Main. $+49(69) 7564-280$, Fax: $+49(69) 7564-201$.

$\checkmark$ June 16/19 '96: Quantitative Image Analysis Short Course (N.C. State Univ.) Taastrup, Denmark (919)515-2261

$\checkmark$ June 19/20 97: 3D Microscopy of Living Cells Short Course and NEW post-course workshop. (Univ of WI \& Univ of B.C.) Vancouver, B.C. James Pawley: (608)263-3147, fax: (608)265-5315

$\checkmark$ June 22/27 '97: Fundamentals and Applications of Light Microscopy. Burlington, VT. Mary McCann: (617)484-7865, Fax: (617)484-2489

$\checkmark$ June 23/27 '97: 13th Annual Short Course on Molecular Microspectroscopy. (Miami University) Oxford, OH. (513)529-2874, Fax: (513) $529-7284$

$\checkmark$ June 23/27 97: OIM Academy: OIM Theory \& Applications (TSL) Provo, UT. Klaus Behnert: (801)344-8990, Fax: (801)344-8997.

$\checkmark$ July 6/9 '97: CRYO '97 - Low Temperature Microscopy and Analysis \& The Application of the Microscope in Life Sciences, Cells, and Signaling Including FLOW. (Royal Microscopical Society). Univ. of York, RMS: $+44(0) 1865248768$, Fax: $+44(0) 1865791237$

$\checkmark$ Aug 10/15 '97: Microscopy Society of America 55th Annual Meeting - Jointly with the Microbeam Analysis Society. Cleveland, OH. MSA Business Office: (800)538-3672. Fax: (508)548-9053

$\checkmark$ Sept 7/11 97: 111th AOAC International Annuyal Meeting \& Eposition. San Diego, CA. (800)379-2622, Fax: (301)924-7089

$\checkmark$ Oct 8/16 '97: Optical Microscopy and Imaging in the Biomedical Sciences (Marine Biological Lab) Woods Hole, MA. Carol Hamel: (508)289-7401.

$\checkmark$ Aug 31 - Sept 4 '98: ICEM XIV/International Congress on Electron Microscopy. Cancun, Mexico. (525)553-4507, Fax: (525)5534500, email: icem@icem.inin.mx 


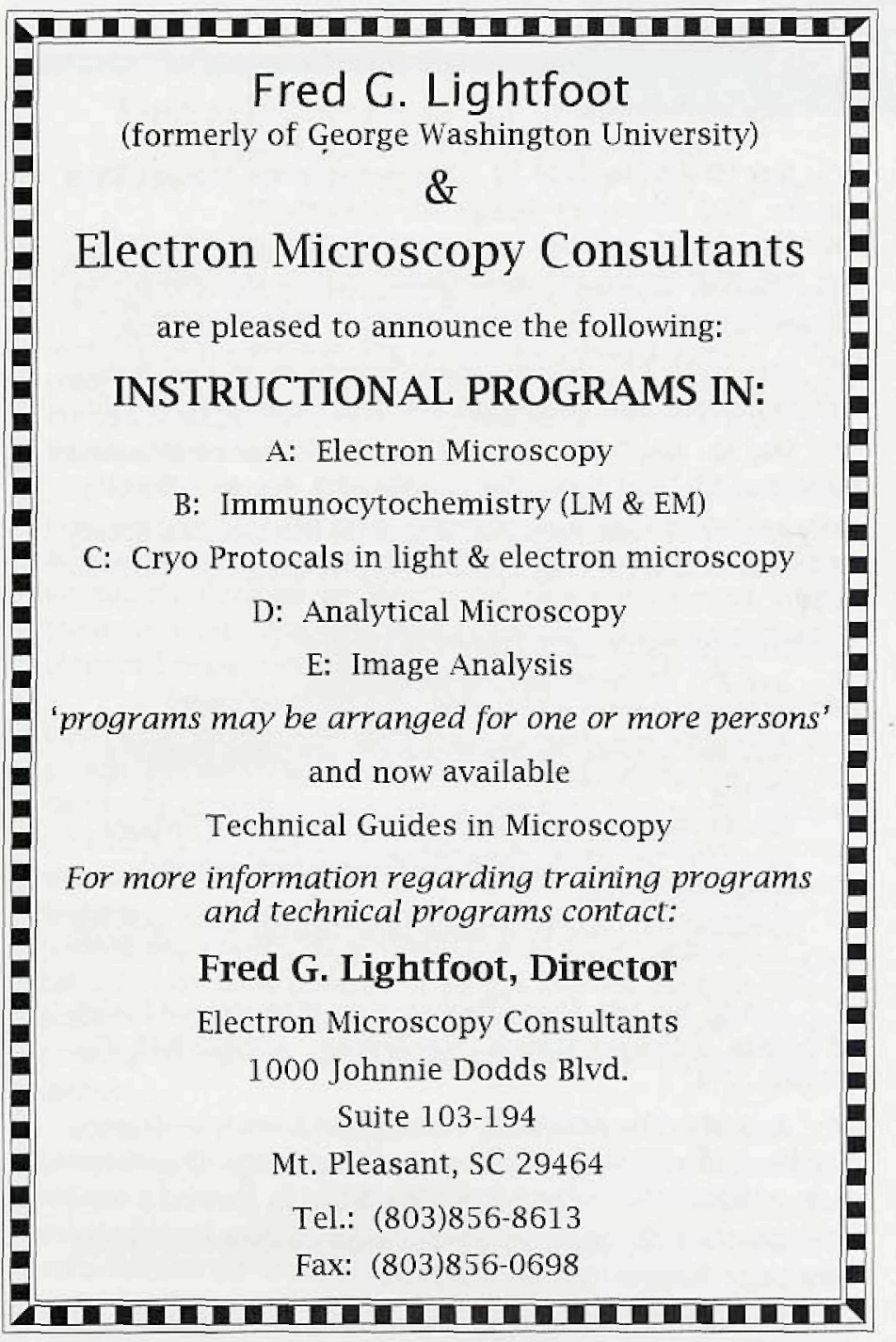

\section{USED EQUIPIIEIT FOR SALE}

율 OLYMPUS MICROSCOPES (all with 4 objs.) All like new! 1) BX-50 (100w): $\$ 5,800,2$ ) BX-40 (30w): $\$ 4,600,3)$ BHS (100w) Research: $\$ 4,800$, All are adaptable to a Photo Tri-Noc., 4) PIM-10 ADS Photomicrography System: $\$ 3,900$, MICROGENICS: (707)277-7909

Reichert Ultracut E Ultramicrotome with vibration table and cyro Asking $\$ 19,000$, Leica Supernova Ultramicotome with table - Asking $\$ 12,000$ Zeiss EM10C - Asking $\$ 17,000$, EM Lab dissolving - many more items. Please call (904)775-4330

MILITARY RESEARCH LAB IS CLOSING - Military contractor is selling at drastically reduced prices its Reichart Polycut $S$ motorized sliding microtome, refrigerated and rotary microtomes, Sorvall uliramicotome, Gatan Model 600 dual ion mill. Fisher embedding center, stereo microscopes, Perkin Elmer microdensitometer and LECO sulfur analyzer. For specification sheets, call: (202) 544-0836.

굼 Hitachi H600 AB TEM with Delta Class Analyzer. Off-lease equipment. Call Richard Berkemeier at Fleet Capital: (401)278-3554

웊 GATAN 600A Dual lon Mill with less than 200 hours time on each gun, great condition; EDAX Detecting Unit Model ECON 2/P505 149-10; SHIMADZU GC-9A Gas Chromatagraph; LINDBERG Tube Furnace Model 55346, 4.5" $\times 30^{\prime \prime}$ tube, 3 Zone Digital Contol; CARL ZEISS MOP3 Digital Image Analyzer; VARIAN Vacuum System; COMPONENTS SYSTEMS CLASS 100 Clean Room, $10^{\prime} \times 15^{\prime}$ Modular with Hepafilter and lighting system in the ceiling, Complete. For more information call IAM Group @(770)434-0031

줄 Peak Instruments System 10 Wavelength Dispersive $X$-ray Analysis System. Configured for $\mathrm{B}, \mathrm{C}, \mathrm{OF}$ and $\mathrm{S}$. Interfaces to IS| 100-B. Asking: \$7,500. Call John at (203)639-1338.
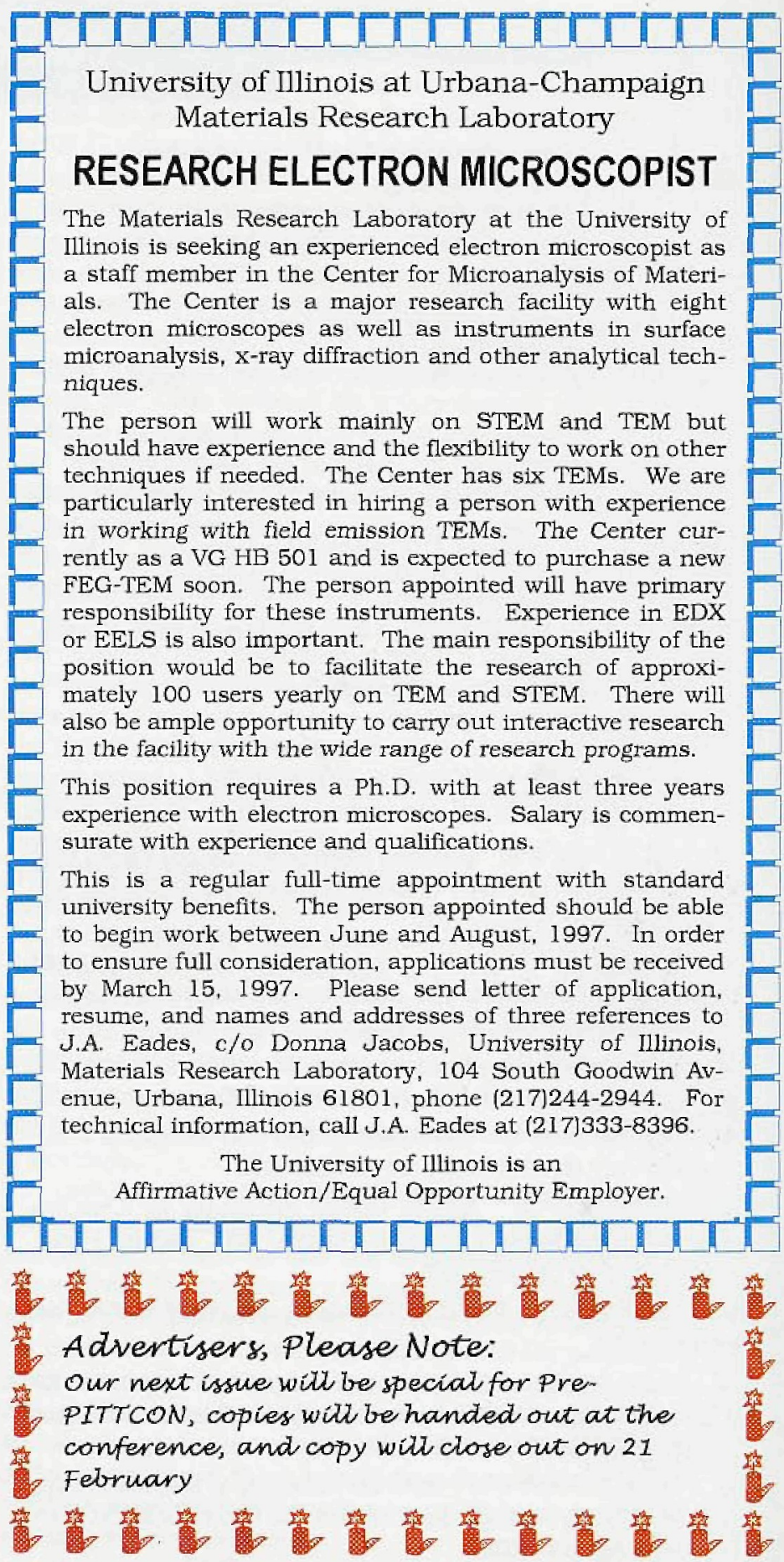

Call to request our new catalog!

Quality E.M. supplies "taylored" to fit your application and budget?

M.E. TAYLOR ENGINEERING, INC.

21604 Gentry Lane • Brookeville, MD 20833

Phone: 1-301-774-6246 FAX: 1-301-774-6711

E-Mail: Metengr@aol.com

VISA AND MASTERCARD ACCEPTED! 

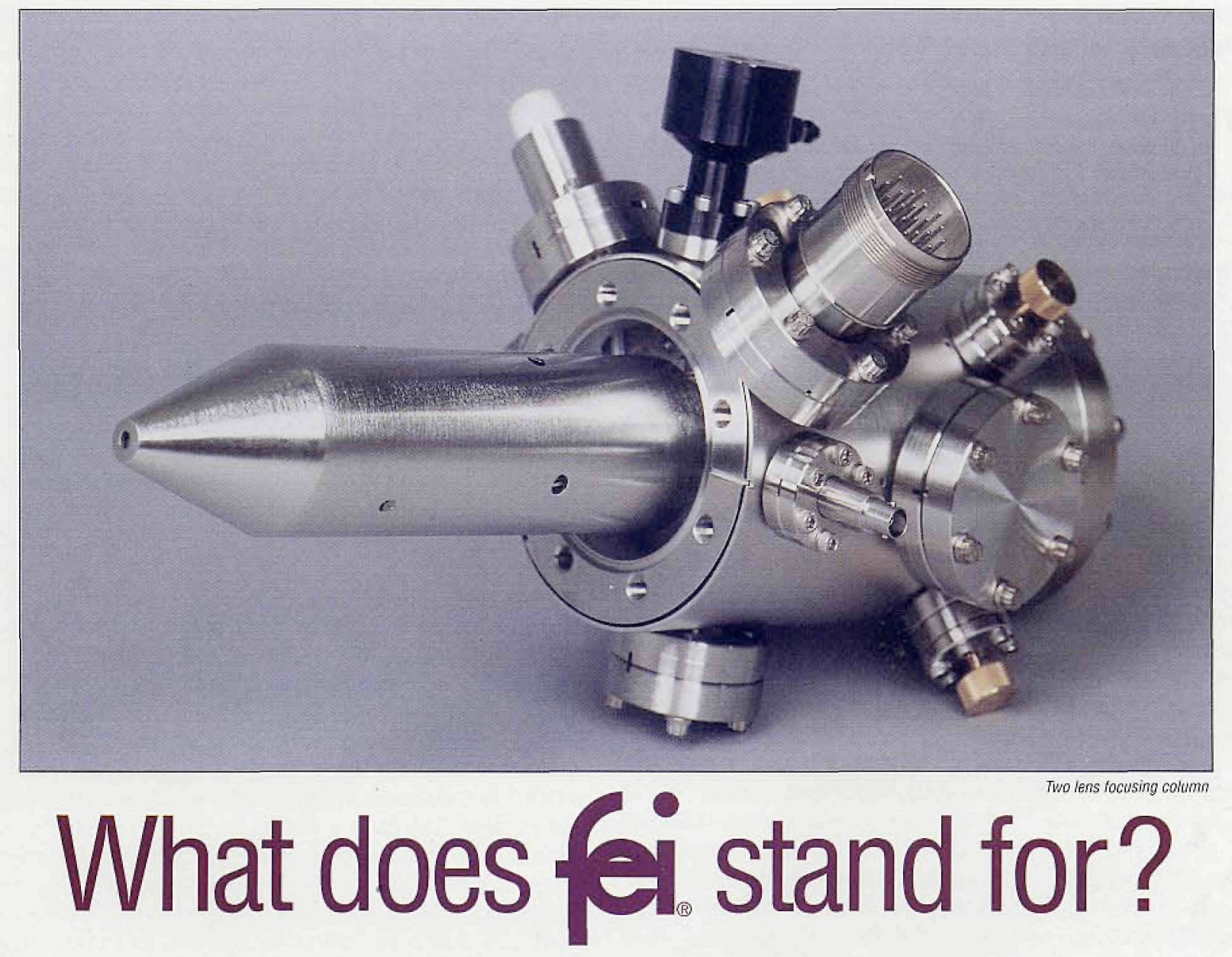

Our compact, UHV, field emission columns are used by researchers world wide. Innovative electrostatic optics and dedicated electronics allow you to integrate a high current density electron or ion column into most vacuum systems. FEI also supplies researchers with other specialized products...

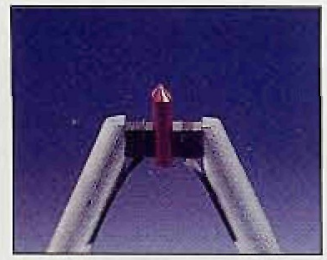

\section{$\mathrm{LaB}_{6}$ an $\mathrm{CeB}_{6}$ Cathodes}

FEl's Mini-Vogel Mount, the first universally compatible long-life, high-stability LaB6 cathode, provides excellent performance and the best cost-per-use value for installation into your EM systems.

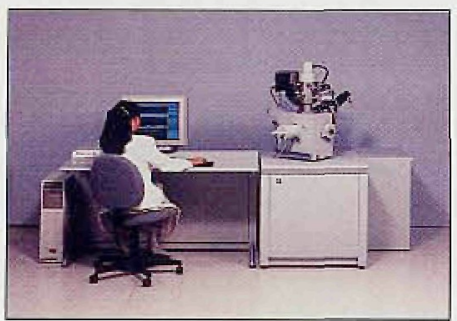

\section{FIB Workstations}

Focused ion beam micromilling workstations range from the 8"-wafer compatible model to the economical 2 " small sample model ideal for semiconductor, biological, TEM, and MEMS specimens.

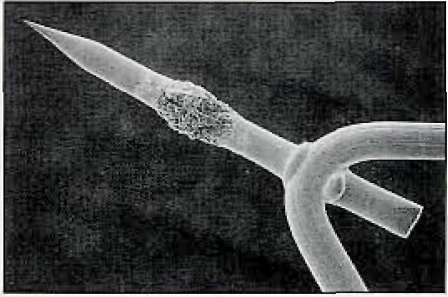

Field Emission Cathodes

FEI supplies Schottky field emitters to EM manufacturers worldwide. Schottky emission's high current intensity has established it as the preferred electron source for high resolution SEM, TEM, Auger, ESCA, $E D X$, and lithography.

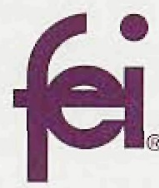

FEI Company

7451 NE Evergreen Parkway

Hillsboro, OR 97124-5830

(503) 640-7500 Fax (503) 640-7509

email:rsk@feico.com

Now, when you think of FEI, you'll know we are the Specialists in Field Electron and Ion Technology. 